\title{
Generation of identical twin piglets following bisection of embryos at the morula and blastocyst stage
}

\author{
B. Reichelt and H. Niemann* \\ Institut für Tierzucht und Tierverhalten (FAL), Mariensee, 31535 Neustadt, Germany
}

\begin{abstract}
Porcine morulae and blastocysts were microsurgically bisected and the resulting zona pellucida-free demi-embryos were either cultured in vitro for $48 \mathrm{~h}$ or transferred after $24 \mathrm{~h}$ of culture into $-24 \mathrm{~h}$ asynchronous recipients. All demi-embryos were evaluated according to morphological criteria and classified into three categories (excellent, fair or degenerated). The average diameter and the number of cells were determined. Of 1162 bisected embryos, 764 pairs $(66 \%)$ were evaluated as transferable after $24 \mathrm{~h}$ of culture in vitro. The average diameter after $48 \mathrm{~h}$ of culture in vitro was different $(P<0.01)$ among demi-embryos of the three morphological categories as was the number of cells. The greatest diameter and the greatest number of cells were found in demi-embryos classified as morphologically excellent. A total of 22 of 27 recipients $(81.5 \%)$ remained pregnant and 21 recipients delivered 126 piglets of which six were stillborn. The survival rate of demi-embryos in farrowing recipients was $21.2 \%$ (126 of 594). Litter size was significantly reduced in recipients after transfer of demi-embryos compared with that of mated controls $(6.0 \pm 2.5$ versus $10.8 \pm 2.1$ piglets). Similarly, the postpartum losses of piglets were higher in the experimental than in the control gilts (26.7\% versus $11.6 \%$ ). Duration of gestation, average birth weight and daily weight gain were not affected. Among the 126 piglets, seven pairs of identical twins $(2.3 \%$ of 311 transferred pairs) were identified using several genetic markers in blood (blood groups, polymorphic enzymes and plasma proteins) in a total of 25 gene loci. DNA fingerprinting revealed an identical banding pattern between the two partners of each of the seven pairs. Birth and weaning weight as well as daily weight gain varied considerably between monozygotic partners.
\end{abstract}

\section{Introduction}

In contrast to the well advanced embryo bisection technology in cattle (Ozil, 1983; Williams et al., 1984; Arave et al., 1987; Seike ef al., 1989; McEvoy and Sreenan, 1990; Gray et al., 1991; Kippax et al., 1991) and small ruminants (Gatica et al., 1984; Willadsen and Godke, 1984; Tsunoda et al., 1985; Chesné et al., 1987; Udy, 1987; Shelton and Széll, 1988; Széll and Hudson, 1991; Shelton, 1992) studies in pigs are scarce and very few sets of identical twin piglets have been obtained upon transfer of bisected pig embryos (Polge, 1985; Nagashima et al., 1988; Ash et al., 1989). The main obstacles to the generation of identical twin piglets are inherent to some characteristics of reproductive physiology of pigs. Pregnancy is only maintained in pigs when a minimum of 2-4 embryos implant and at least $25 \%$ of the uterine surface is covered by embryonic tissue (Polge et al., 1966; Webel et al., 1970). Furthermore, the transuterine migration during the preimplantation phase (Dziuk et al., 1964) does not allow a separate transfer of demi-embryos into each uterine horn, which complicates identification of monozygosity. Identification of monozygosity requires the

*Correspondence and reprint requests.

Received 25 March 1993. analysis of genetic polymorphisms using genetic markers (blood groups, polymorphic enzymes, plasma proteins) for which established procedures are available (Hesselholt, 1966; Schmid and Buschmann, 1985; Juneja and Gahne, 1987). These methods are routinely used to characterize the genetic identity of individual animals. DNA-fingerprinting has been introduced to test monozygosity (Pemberton and Amos, 1990). The procedure is based on the observation that in many organisms short repeated DNA sequences are found at numerous positions in the genome. The basic unit of these simple repetitive DNA sequences is a few base pairs that are located in the noncoding regions between genes. The number of repeats of the simple sequences and the restriction enzyme sites in the noncoding regions are highly variable and can therefore be used to identify the genetic identity of an individual (Jeffreys et al., 1985; Nakamura et al., 1987). A reliable procedure for generation and identification of identical twin piglets would be valuable for both the employment of new breeding strategies and for basic biomedical research.

The purpose of our investigation was to test the efficiency of obtaining monozygotic twin piglets following microsurgical bisection of morula and blastocyst stages and to elucidate the suitability of DNA-fingerprinting for improving identification of identical twins among the piglets that are born. 


\section{Materials and Methods}

\section{Animals and embryos}

Prepubertal German Landrace gilts (182-246 days of age, $78-123 \mathrm{~kg}$ bodyweight) were used either as donors or as recipients. Superovulation was induced by i.m. injections of 1500 iu pregnant mares' serum gonadotrophin (PMSG: Intergonan; Vemie, Kempen) followed $72 \mathrm{~h}$ later by an i.m. injection of 500 iu hCG (Ekluton, Vemie, Kempen). Donors were mated to a fertile German Landrace boar 24 and $48 \mathrm{~h}$ after administration of hCG. When appropriate boars were not available, semen was collected and the donors were inseminated with $100 \mathrm{ml}$ of at least $2 \times 10^{9}$ freshly diluted spermatozoa. Blood samples were collected from the cava anterior vein of donors for determination of genetic parentage. The day of the first mating or insemination was designated as day 0 . The recipients underwent a parallel treatment (800 iu PMSG, Intergonan), but $24 \mathrm{~h}$ behind the schedule of the donors, making them $-24 \mathrm{~h}$ asynchronous to the donors. Oestrus was detected using test boars and only females showing clear signs of oestrus and accepting the boar were used as potential recipients. Three to four donors (in total 103) were used per experimental day and at the same time two to three recipients (in total 32) were prepared. The selection and mating of the donors for an experimental day took into account the fact that the parents of the potential embryos to be bisected were not related to each other, to facilitate the determination of parentage and monozygosity. All matings or inseminations of one particular donor were done by the same boar. There were no siblings among the donors and boars assigned to an experimental day. Donors were killed on day 5 at the Institute's abattoir and the genital tract was removed immediately. At the same time, blood samples were taken for tests of parentage and monozygosity. Within 5 to $10 \mathrm{~min}$ after killing the animals, the uterine horns were flushed using standardized procedures and the morphological quality of the collected embryos was assessed (Niemann et al., 1983a; Niemann and Elsaesser, 1987). Subsequently, morulae and blastocysts classified as excellent or good from one individual donor animal were placed into $2 \mathrm{ml}$ Dulbecco's phosphate-buffered saline (PBS - Sigma, St Louis, MO) supplemented with $10 \%$ newborn calf serum (NBCS, Boehringer, Mannheim) at $37^{\circ} \mathrm{C}$ in a humidified atmosphere with $5 \% \mathrm{CO}_{2}$ in air until being used for microsurgical bisection.

\section{Microsurgical bisection of pig embryos}

The microsurgical bisection was performed at room temperature using a micromanipulation unit consisting of an inverted microscope (Diavert, Leitz, Wetzlar) and a mechanical micromanipulator (Leitz) which was placed on the right side of the microscope. All embryos were bisected using a sterile microsurgical blade (Spezialklinge S, Heidelberg) which was fixed with a special blade holder (Frohnhäuser, Munich) without a holding pipette. Bisection was done under a microscope at $\times 100$ magnification in a droplet of medium (PBS supplemented with 10\% NBCS) covered with silicone oil. The embryos were fixed during bisection by scratching the bottom of the plastic Petri dish with the microblade. The microblade was held above the embryo placed between two scratches parallel to the blade. The microblade was brought slowly down and the embryos were bisected and the zona pellucida was cut into two pieces. The inner cell mass of blastocysts was carefully separated into two halves. All demi-embryos were cultured or transferred without zona pellucida. Only one embryo was bisected per droplet of medium and each Petri dish contained three droplets of medium. It was thus possible to split three embryos successively within approximately $10 \mathrm{~min}$. Immediately after bisection all demi-embryos were transferred into culture medium.

\section{In vitro culture of demi- and intact embryos}

A representative number of nonbisected embryos from each donor animal was cultured as controls. These were approximately $20-25 \%$ of the embryos randomly collected at an experimental day, at the same stage of development and of the same morphological quality score as the embryos used for bisection. The culture medium was Krebs-Ringerbicarbonate solution (KRB) (Davis and Day, 1978) modified (mKRB) according to Saito and Niemann (1991); mKRB lacked lactate and pyruvate but contained EDTA and contained a higher concentration of $\mathrm{NaCl}\left(1.168 \mathrm{~g} \mathrm{l}^{-1}\right)$. The mKRB solution was supplemented with $10 \%$ heat-inactivated lamb serum (Seromed, Berlin; heat inactivated for $30 \mathrm{~min}$ at $56^{\circ} \mathrm{C}$ ), sterile filtered and stored at $4^{\circ} \mathrm{C}$ for a maximum of 7-10 days. Only one pair of demi-embryos was cultivated per Petri dish at $37^{\circ} \mathrm{C}$ in a humidified atmosphere with $5 \% \mathrm{CO}_{2}$ in air (Niemann and Elsaesser, 1987), for either $24 \mathrm{~h}$ when they were to be transferred to recipients or a total of $48 \mathrm{~h}$ when development in vitro only was studied (Table 1 ). Embryos used exclusively for in vitro culture were collected on 5 experimental days. In addition, demi-embryos collected for transfer and not used for this purpose were similarly cultured in vitro.

The development of the demi-embryos was evaluated after $24 \mathrm{~h}$ using morphological criteria such as rounding up of the halves, formation of a blastocoel and the incidence of excluded degenerated cells. All halves were classified into three groups according to Nagashima et al. (1989): category I: typical blastocysts with very few degenerated cells $(<10 \%)$ and a clearly visible inner cell mass (excellent); category II: blastocysts of a smaller diameter than group I with a larger number of degenerated cells (10-20\%) and the inner cell mass not clearly visible (fair); category III: small blastocysts without a visible inner cell mass and a large number of degenerated cells $(>20 \%)$ or some enlarged nonintegrated blastomeres or completely degenerated halves (degenerated).

A pair of demi-embryos was evaluated as being transferable only when both halves were classified at least into category II.

\section{Transfer of demi-embryos}

In cases in which too few transferable pairs (in total 394) were available, single halves $(n=22)$ classified into category I were cotransferred to increase the probability of maintaining pregnancy. In total, 810 halves were washed twice in PBS 
Table 1. Classification of pairs of pig demi-embryos following $24 \mathrm{~h}$ of culture in vitro and their distribution in in vitro and in vivo experiments

\begin{tabular}{|c|c|c|c|c|c|c|c|}
\hline Classification & $\mathrm{I} / \mathrm{I}$ & $\mathrm{I} / \mathrm{II}$ & II/II & $\mathrm{I} / \mathrm{III}$ & Il/III & III/III & Total \\
\hline$n$ & 332 & 320 & 112 & 170 & 143 & 85 & 1162 \\
\hline$\%$ & 29 & 27 & 10 & 15 & 12 & 7 & \\
\hline \multicolumn{8}{|l|}{ In vitro culture } \\
\hline$n$ & 85 & 205 & 80 & $146^{*}$ & 143 & 85 & \\
\hline$\% * *$ & 11 & 27 & 11 & - & - & - & \\
\hline \multicolumn{8}{|l|}{ Transfer } \\
\hline$n$ & 247 & 115 & 32 & $22^{*}$ & - & - & \\
\hline$\% * *$ & 32 & 15 & 4 & - & - & - & \\
\hline
\end{tabular}

I = excellent morphology; II = good morphology; III = degenerated.

Only demi-embryos in categories I and II were considered as transferable. ${ }^{*}$ A total of 22 single demi-embryos were transferred.

**Percentage levels related to transferable embryos only.

supplemented with $5 \%$ NBCS and were then transported at $37^{\circ} \mathrm{C}$ to the site of transfer approximately $8 \mathrm{~km}$ from the laboratory. Food was withheld for $24 \mathrm{~h}$ before the surgical intervention in the recipients. Anaesthesia was induced by an i.m. injection of $200 \mathrm{mg}$ Azaperon (Stresnil, Jansen, Neuss) followed 20 min later by an i.v. injection of Metomidathydrochlorid (Hypnodil, Jansen, Neuss) into the ear vein at 500-1000 mg per animal to ensure the onset of a suitable anaesthetic stage. The abdominal cavity was opened in the linea alba, and the ovaries were exposed and checked for the presence of a sufficient number of corpora lutea. Transfers were performed only when at least six corpora lutea could be detected. A $1 \mathrm{ml}$ syringe was used to suck the demi-embryos with the least transfer medium possible into a sterile transfer catheter (Ernährungssonde Braun, Melsungen). The uterine wall of one horn was punctured by a blunt metal needle and the transfer catheter was inserted approximately $2-3 \mathrm{~cm}$ into the uterine lumen where the demi-embryos were deposited. The abdominal cavity was then closed using standardized surgical procedures and all animals received a prophylactic penicillin-streptomycin treatment. All recipients were checked for signs of oestrus at the next expected day of oestrus by inspection of the vulva and testing with a boar. At about day 45 after transfer, the animals underwent an ultrasound examination (Picker CS 9000 with a $5 \mathrm{MHz}$ probe). Recipients that did not show signs of oestrus and in which fetuses could be detected were considered pregnant. Blood samples were collected from all piglets at approximately $4-6$ weeks of age to test for monozygosity. This schedule for collecting blood samples was necessary as the various electrophoretic analyses required a total of $15 \mathrm{ml}$ blood and we had previously found that collection of $10-15 \mathrm{ml}$ blood from newborn offspring interfered with the health and subsequent development of the piglet.

The further development of the piglets derived from transfer of demi-embryos was compared using 20 gilts (controls) that had been mated at their first oestrus to boars involved in this study. Both the recipients and controls were randomly selected during the same period from the same pool of animals in our experimental herd and were of the same age and bodyweight.
Determination of diameter and number of cells in demi-embryos developed in vitro

After culture in vitro the diameter and number of cells were determined from a representative percentage $(6-14 \%)$ of embryos randomly selected from controls and demi-embryos in each morphological category. The diameter was measured at a magnification of $\times 100$ (Axiovert $35 \mathrm{M}$, Zeiss, Oberkochem) using a micrometer. The zona pellucida was removed by a short-term incubation in a $1 \%$ pronase solution (Protease: Sigma) in control embryos that had not hatched from the zona pellucida at the end of the culture period. Subsequently halves and controls were prepared for counting the number of nuclei as described by Tarkowski (1966). After hypotonic treatment, fixation and drying at room temperature, all preparations were stained with a $10 \%$ Giemsa solution. The stained nuclei were counted at a magnification of $\times 250$ (M20; Wildt, Heerbrugg).

\section{Determination of monozygosity}

Each recipient received demi-embryos from a maximum of four different genetic parents. The parentage of piglets was determined by typing the genetic parents and piglets according to blood genetic markers (blood groups, plasma proteins and polymorphic enzymes). Monozygotic twins could be identified by comparing the various parameters among piglets of the same sex within one litter. Blood was stabilized in a solution of $2 \%$ sodium citrate, $0.5 \%$ sodium chloride and $0.06 \%$ sodium cyanamide in double-distilled water using agglutination and haemolysis procedures (Schmid and Buschmann, 1985; Vögeli, 1990) and 15 blood group systems involving 58 factors were determined. The serum and enzyme systems were determined electrophoretically; the AMY- and TF-system in starch gel, the GPI-, PGD-, PGM- and ADA-system in an agarose gel (Verhorst, 1973), the A1BG-, PI-1, PI-2 and PI-3-system were analysed by two-dimensional electrophoresis (Juneja and Gahne, 1987). In total, 25 gene loci were involved.

Blood samples from piglets that were identified as identical twins by blood genetic markers underwent a DNA-fingerprinting procedure to confirm their genetic identity. Approximately $20 \mathrm{ml}$ blood was collected, treated 


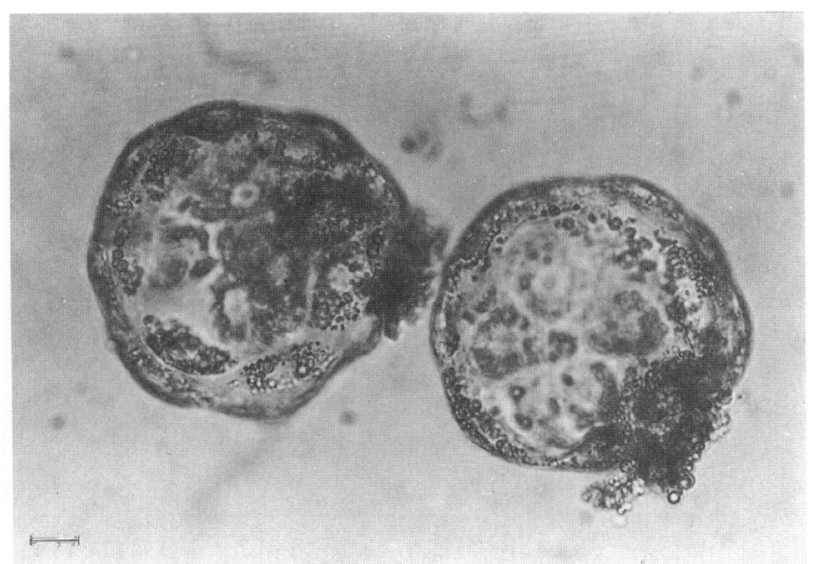

Fig. 1. A pair of pig demi-blastocysts after culture in vitro for $24 \mathrm{~h}$; both are classified as excellent (I/I). The inner cell mass is visible and only very few degenerated cells are apparent. Scale bar represents $25 \mu \mathrm{m}$.

with EDTA and then stored frozen at $-20^{\circ} \mathrm{C}$. For DNAfingerprinting, the DNA was extracted (Miller et al., 1988) and digested with the restriction enzyme Hinf I. All hybridizations were performed with the ${ }^{32} \mathrm{P}$-radiolabelled probe $(\mathrm{GGAT})_{4}$ (Epplen and Zischler, 1991; Schwaiger et al., 1992).

\section{Statistical analysis}

Normal distributed variables such as diameters of embryos and birth weights of the piglets were analysed by the general least-squares method (GLM) (Searle, 1971). Random test comparisons were calculated with Students $t$ test for significant differences. Qualitative traits that were discontinuously distributed as binominal or multinominal data (Grizzle et al., 1969) were analysed using the nonparametric Catmod procedure of the SAS statistical package (SAS version 6.04, 1989). The data are presented as means \pm SD. Differences were considered to be significant at $P<0.05$.

\section{Results}

From 91 donors an average of $42.1 \pm 18.2$ corpora lutea were obtained yielding 3017 ova and embryos and total recovery rate was $78.8 \%$ (33.2 \pm 17.7 ova and embryos per donor). Fertilization rate was $82.2 \%$ and of the 2481 fertilized ova 2236 (90.1\%) were classified as viable and were at the compacted morula to expanded blastocyst stage. A total of 1162 embryos, including 172 compacted morulae, 496 early blastocysts and 494 blastocysts, were microsurgically bisected in 27 experimental replicates.

\section{Morphology of pig demi-embryos after 24 and $48 \mathrm{~h}$ of culture in vitro}

Sixty-six per cent (764) of the 1162 pairs of demi-embryos were considered transferable after $24 \mathrm{~h}$ of culture in vitro (Table I; Figs $1-3$ ). The pairs that were not transferred to recipients underwent continuous culture for a further $24 \mathrm{~h}$

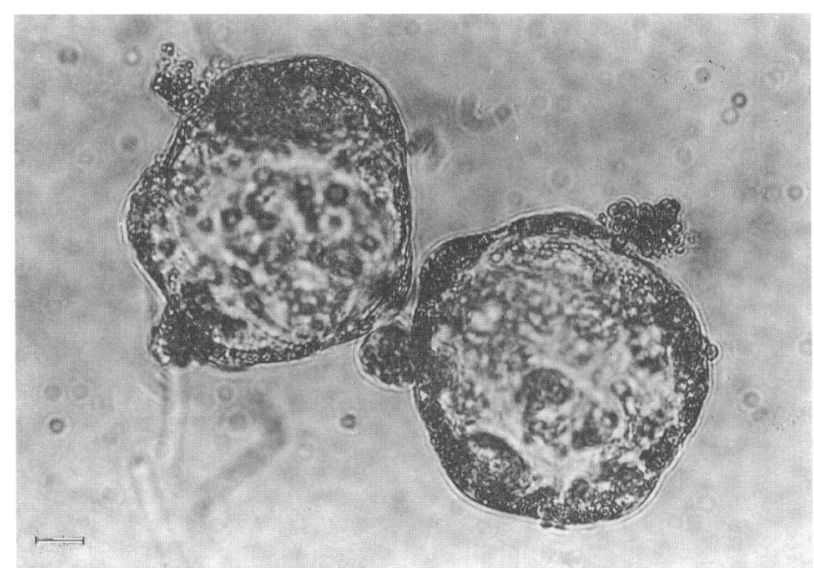

Fig. 2. A pair of pig demi-embryos after culture in vitro for $24 \mathrm{~h}$; both are classified as fair (II/II). The inner cell mass is not clearly visible and a few degenerated cells are adhering to the blastocoel. Scale bar represents $25 \mu \mathrm{m}$.

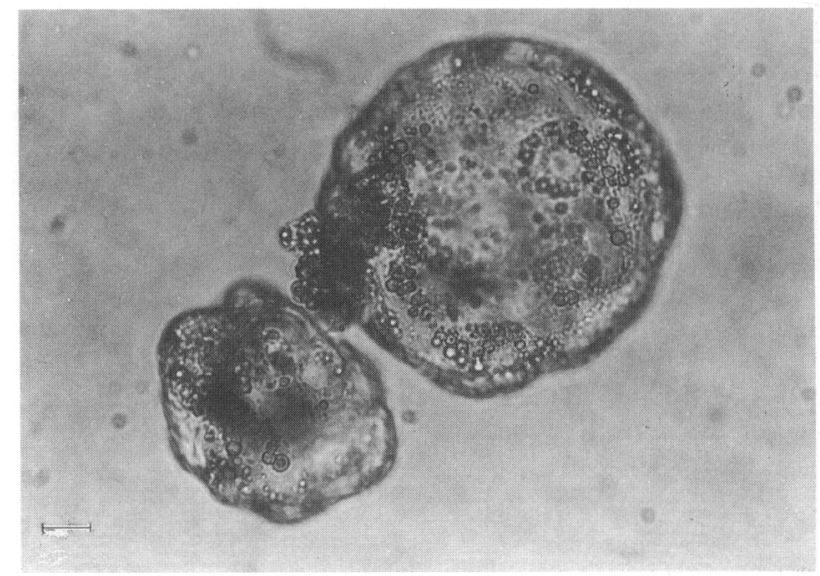

Fig. 3. A pair of pig demi-blastocysts after culture in vitro for $24 \mathrm{~h}$; one-half is classified as excellent, the other as degenerated (I/III). Scale bar represents $25 \mu \mathrm{m}$.

before being evaluated again. In $61.6 \%$ of the pairs, the morphological classification was not altered compared with the preceding evaluation. In $18.8 \%$, one-half received a better grade than $24 \mathrm{~h}$ before, and in $18.2 \%$ one-half had an impaired morphology. In 8 pairs (1.3\%) one-half showed an improved, whereas the other half displayed an impaired, morphology compared with the first evaluation after $24 \mathrm{~h}$ of culture in vitro. The percentage of transferable pairs was different $(P<0.05)$ among blastocysts $(71 \%)$, early blastocysts $(65 \%)$ and morulae $(53 \%)$.

\section{Diameter of demi-embryos after culture in vitro for $48 \mathrm{~h}$}

The average diameter of demi-embryos classified in category I was greater $(P<0.01)$ than that of demi-embryos of categories II and III. The diameter of embryos in category II and III demi-embryos was also different $(P<0.01)$. The average diameter in control embryos was similar to that in demi-embryos of category I (Table 2). When considering the 
Table 2. Average diameter $(\mu \mathrm{m})$ of porcine demi-embryos and controls after culture in vitro for $48 \mathrm{~h}$

\begin{tabular}{lccccc}
\hline Category & $n$ & Mean & SD & Minimum & Maximum \\
\hline I & 70 & $210.6^{\mathrm{a}}$ & 33.1 & 150 & 290 \\
II & 77 & $161.6^{\mathrm{b}}$ & 25.7 & 110 & 220 \\
III & 29 & $121.7^{\mathrm{c}}$ & 25.6 & 70 & 161 \\
Controls & 42 & $213.7^{\mathrm{a}}$ & 25.2 & 170 & 280 \\
\hline
\end{tabular}

I = excellent morphology; II = good morphology; III = degenerated. ${ }^{a, b, c}$ Values with different superscript letters are significantly different $(P<0.01)$.

Table 3. Average number of cells in pig demi-embryos and controls after culture in vitro for $48 \mathrm{~h}$

\begin{tabular}{lccrcr}
\hline Category & $n$ & Mean & SD & Minimum & Maximum \\
\hline I & 99 & $54.0^{\mathrm{a}}$ & 18.5 & 22 & 114 \\
II & 93 & $25.7^{\mathrm{b}}$ & 8.6 & 10 & 56 \\
III & 41 & $14.3^{\mathrm{c}}$ & 6.7 & 6 & 36 \\
Controls & 67 & $81.8^{\mathrm{d}}$ & 28.6 & 41 & 139 \\
\hline
\end{tabular}

I = excellent morphology; II = good morphology; III = degenerated. $a, b, c, d$ Values with different superscript letters are significantly different $(P<0.01)$.

average diameter in halves of categories I and II in relation to the classification of the respective partner, it became evident that, even when the two halves were classified into the same category, they were not the same size. The difference between halves both classified in category I was $19.4 \mu \mathrm{m}$ and in halves both classified in category II $14.6 \mu \mathrm{m}(P<0.05)$.

Number of cells in demi-embryos after culture in vitro for $48 \mathrm{~h}$

The average number of nuclei was highest in demiembryos classified in category I and was different $(P<0.01)$ from that of halves in categories II and III, as was the difference between demi-embryos in categories II and III $(P<0.01)$. The average number of nuclei in control embryos was higher $(P<0.01)$ than that in demi-embryos of category I (Table 3). When the average number of nuclei was considered in relation to the respective partner, there were no differences in demi-embryos classified into category II. However, the number of cells in demi-embryos both classified in category I was different $(P<0.01)$ between partners (36 versus 54 ). Similarly, halves classified into category I possessed a greater number of cells when the respective partner was classified into category II or III $(58$ and 69 nuclei, respectively). The number of cells and the average diameter were closely correlated $(r=+0.85)$.

\section{Development of pig demi-embryos in vivo}

Because of the technical difficulties in collecting larger numbers of zona-free blastocysts in a very small amount of
Table 4. Fertility parameters in gilts delivering piglets derived from demi-embryos or after mating (controls)

\begin{tabular}{lcc}
\hline Parameter & $\begin{array}{c}\text { Experimental } \\
\text { animals }\end{array}$ & Controls \\
\hline Duration of gestation (days) & $115.5 \pm 2.3$ & $114.7 \pm 1.3$ \\
Litter size & $6.0 \pm 2.5^{\mathrm{a}}$ & $10.8 \pm 2.0^{\mathrm{b}}$ \\
Birth weight (kg per piglet) & $1.1 \pm 0.4$ & $1.3 \pm 0.2$ \\
Daily weight gain $(\mathrm{g})$ & $228.2 \pm 43.6$ & $209.1 \pm 39.5$
\end{tabular}

a,b Values with different superscript letters are significantly different $(P<0.01)$

medium in the transfer catheter, only 759 demi-embryos were transferred corresponding to approximately 28 halves per recipient. A total of 22 of 27 recipients did not show signs of oestrus and were found to be pregnant at ultrasound scanning $(81.5 \%)$. In total, 21 recipients $(77.8 \%)$ farrowed and in 20 of these parturition occurred spontaneously and without problems. On day 120 after transfer, one recipient received an i.m. injection of a prostaglandin-analogue $(250 \mu \mathrm{g}$ Estrumate: Pitman-Moore, Grossburgwedel) to induce parturition and a stillborn piglet was delivered $20 \mathrm{~h}$ later. In total, 126 piglets were born of which 120 were alive. When the number of piglets born was related to the number of transferred halves in all 27 recipients, $16.6 \%$ (126 of 759 ) developed to piglets; when related only to the 21 farrowing recipients this percentage was $21.2 \%$ (126 of 594).

Litter size differed $(P<0.01)$ between the recipients and control animals, whereas duration of gestation, average birth weight and the daily weight gain were similar among the piglets of the two groups (Table 4). Of the 126 piglets, $70(55.6 \%)$ were male and $56(44.6 \%)$ were female. The corresponding figures for the 216 control piglets were $61.6 \%$ $(n=133)$ and $38.4 \%(n=83)$. The recipients delivered a total of six dead piglets (five female, one male) $(4.8 \%$ ), whereas the control animals delivered only one dead male piglet $(0.5 \%)$. The losses up to weaning were $26.7 \%$ ( 32 of 120 ) in piglets derived from demi-embryos and $11.6 \%$ (25 of 215 ) in the controls $(P<0.05)$. Approximately $72 \%$ of these piglets died because of insufficient development or because of maltreatment by the foster mother; the corresponding percentage for the controls was $88 \%$ ( 22 of 25 ). Eight piglets $(6.4 \%)$ derived from the demi-embryos displayed anomalies such as cryptorchism, atresia ani, hernia formation and ventral cleft formation, compared with six $(2.8 \%)$ control piglets; the difference was not significant.

\section{Determination of parentage and monozygosity}

In 93 of 120 piglets born alive ( 51 males and 42 females), blood samples were collected to determine parentage and monozygosity; the remaining 17 males and 8 females died before blood samples could be collected. Blood samples were not collected from one male and one female piglet as they had only one sibling of the opposite sex and therefore could not have a monozygotic twin partner. When using the blood genetic markers, 86 piglets could be related to their genetic parents; in five offspring within a litter of nine piglets, this was 


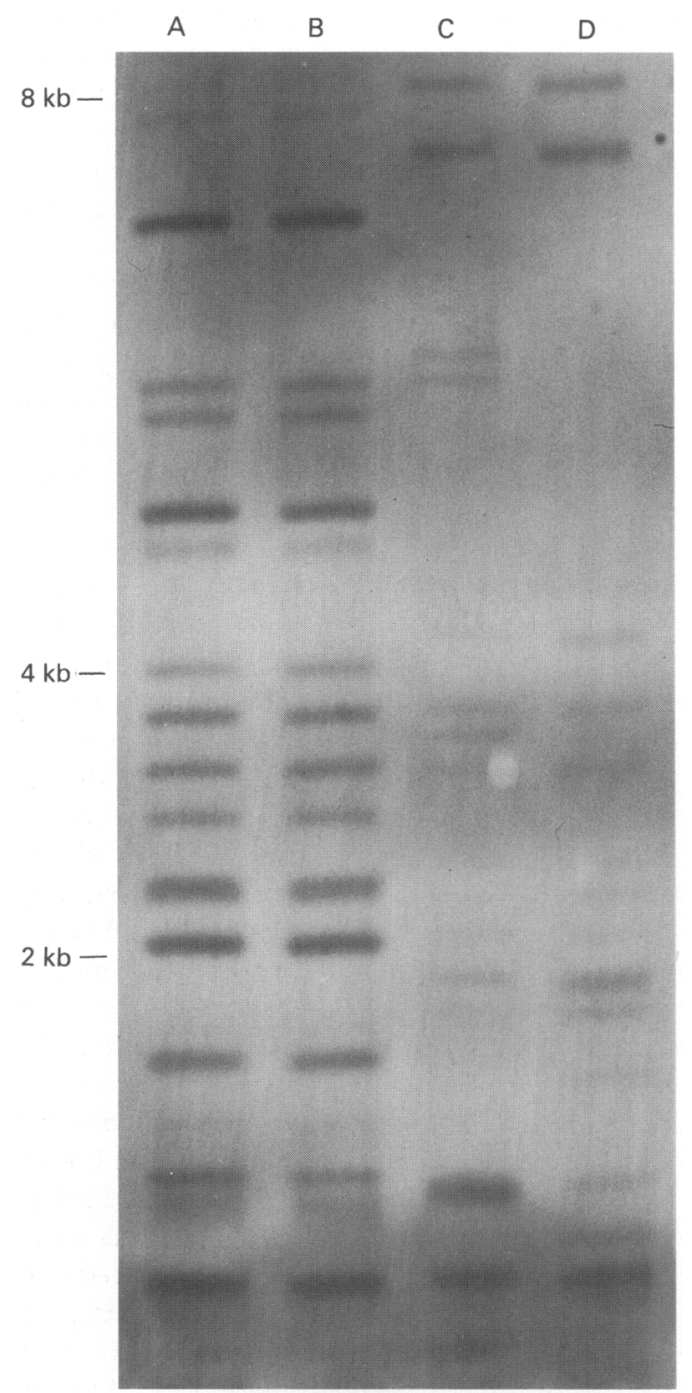

Fig. 4. Banding pattern of a set of identical twin piglets ( $A$ and $B$ ) and of two nonrelated animals ( $C$ and $D$ ). The twins have an identical banding pattern, whereas the other siblings do not share common bands in all positions. Only the section with the best visible bands is shown.

not possible. Seven pairs of monozygotic twin piglets were identified. The monozygosity was confirmed in all pairs by DNA-fingerprinting, as all loci contained identical bands (Fig. 4). The seven pairs of identical twins had a different birth weight (60-320 g difference) and weaning weight (400-5800 $\mathrm{g}$ difference) as well as a different daily weight gain (10-186 $\mathrm{g}$ difference) (Table 5).

\section{Discussion}

The results of the investigation reported here demonstrate that pig demi-embryos possess a great developmental potential in vitro but their development in vivo is impaired compared with that of intact embryos. The level of blastocyst development in vitro $(79 \%)$ in our experiments compared favourably with that reported by Nagashima et al. (1989), who obtained a
Table 5. Birth weight, weaning weight and daily weight gain in monozygotic piglets

\begin{tabular}{lccc}
\hline Sex & $\begin{array}{c}\text { Birth weight } \\
(\mathrm{g})\end{array}$ & $\begin{array}{c}\text { Weaning weight } \\
(\mathrm{kg})\end{array}$ & $\begin{array}{c}\text { Daily weight gain } \\
(\mathrm{g})\end{array}$ \\
\hline \multirow{2}{*}{ Female } & 1140 & 9.8 & 241 \\
Female & 1360 & 10.4 & 251 \\
& 1500 & 9.4 & 214 \\
Male & 1620 & 10.2 & 232 \\
& 1340 & 9.2 & 207 \\
Male & 1440 & 10.3 & 233 \\
& 1600 & 5.5 & 122 \\
Female & 1460 & 11.3 & 308 \\
& 1160 & 10.1 & 224 \\
Male & 1340 & 13.1 & 294 \\
& 1120 & 10.0 & 222 \\
Female & 1180 & 9.6 & 211 \\
& 1160 & 9.9 & 243 \\
& 840 & 9.0 & 227 \\
\hline
\end{tabular}

higher percentage of transferable pairs of demi-embryos (85\%) than in our experiments (66\%). This higher percentage could be attributed to the different bisection technology used. However, the percentage of pairs of demi-embryos classified into category I was similar in both of these studies. The diameter and the number of cells in demi-embryos of the three morphological categories reflected the morphological evaluation of the halves. The close correlation between diameter and number of cells allows the size of the embryo to be used as a major criterion for the evaluation of pig demi-embryos after culture in vitro. Saito et al. (1991) reported that the average diameter of pig demi-embryos derived from bisected morulae or early blastocysts after 72 to $96 \mathrm{~h}$ of culture in vitro was higher than that found in the study reported here $(288-310 \mu \mathrm{m}$, 95-126 cells).

The relative number of cells in demi-embryos, for example the average number of cells of demi-embryos in relation to that of the control embryos, can be used as an appropriate parameter to evaluate the developmental potential of demiembryos. In cows, the relative number of cells in demiblastocysts derived from early or late morulae was exactly $50 \%$ (Bredbacka et al., 1991). We found a relative number of cells of $18 \%, 31 \%$ and $66 \%$ in categories III, II and I demi-embryos, respectively. If the loss of $10-15 \%$ cells caused by a microsurgical bisection (Skrzyszowska and Smorag, 1989) is taken into account, demi-embryos classified in category I possess a high regeneration potential. This is underlined by the finding that the average diameter of these demi-embryos is almost identical to that of the control embryos. Halves of a particular pair were occasionally not of the same size (categories I and II) and number of cells (category I), even when they were classified into the same morphological category. Picard et al. (1986) reported a similar observation for cows with a mean difference of 23 blastomeres. These above findings clearly show the difficulty in splitting embryos in such a way that both halves contain an even number of viable cells and illustrates that some embryos were divided into two unequal parts. However, the percentage of cells destroyed during bisection 
could have been greater in one half than in the other without being detected at the time of bisection, reflecting the difficulty in obtaining a thorough morphological evaluation. However, demi-embryos were cultured without zonae, whereas the control embryos were cultured with an intact zona pellucida. After $48 \mathrm{~h}$ of culture in vitro, nonbisected pig embryos in which the zona pellucida had been removed by a short-term pronase treatment contained more cells than did embryos cultured with an intact zona pellucida (Niemann et al., 1983b). It is assumed that the zona pellucida can play an important role in the regulation of cell division and that, in the early absence of the zona pellucida, blastomere multiplication is enhanced. However, it is possible that the zona pellucida-free demi-embryos can fuse in the uterus to form viable chimaeras. Results from the analysis of the blood genetic markers suggest that this could occur in a small percentage of the piglets going to term.

In the study reported here, the percentage of transferable pairs was higher after bisection of blastocysts than that in morulae. In cattle, bisected blastocysts resulted in higher pregnancy rates than in morulae (Williams et al., 1984; McEvoy and Sreenan, 1990). In small ruminants, expanded blastocysts and even hatched blastocysts yielded better pregnancy rates than did earlier stage embryos (Tsunoda et al., 1985; Chesné et al., 1987; Shelton, 1992). No such observations have been made in pigs, although embryos from day $4-7$ were successfully bisected (Nagashima et al., 1988, 1989; Ash et al., 1989) and in our experiment no separate transfer of demi-embryos derived from either blastocysts or morulae could be done. Apart from the developmental stage of the parent embryos, we identified several other factors that had a significant effect on the percentage of transferable pairs of demi-embryos, such as quality of the parent embryos, duration of the culture in vitro before bisection and the individual donor (Niemann and Reichelt, 1993).

The transfer of 14-16 pig demi-embryos per recipient yielded only low $(<40 \%)$ pregnancy rates (Nagashima et al., 1988, 1989; Ash et al., 1989). These low pregnancy rates could have been due to a higher incidence of early embryonic mortality which regularly reaches $35 \%$ until day 25 of pregnancy (see Pope et al., 1990). In contrast, we transferred an average of 28 demi-embryos per recipient and together with the selection of viable demi-embryos after $24 \mathrm{~h}$ of culture for transfer, this could have led to the high pregnancy rates of approximately $80 \%$, which compare favourably with the pregnancy rates obtained after transfer of intact embryos (Polge, 1982; Niemann, 1989). Whereas the pregnancy rate obtained in our investigation was similar to that after transfer of intact embryos or after mating, litter size was considerably reduced. A similar finding was observed after transfer of intact embryos cultured in vitro (Pope and Day, 1977; Davis and Day, 1978; Niemann, 1989). It is not known whether the culture in vitro or the reduction in numbers of cells contributed more to the higher embryonic losses, whereas a crowding effect can probably be ruled out (Bazer et al., 1969; Pope et al., 1972). Our results suggest that the insufficient developmental potential in vivo of some of the transferred demi-embryos is the main reason for the relatively small litter size. We cannot rule out the possibility that demi-embryos classified into category I had a higher development in vivo than did demi-embryos scored into category II. But most of the transferred demi-embryos were classified into category I. The data obtained in vitro clearly show that only excellent graded demi-embryos (category I) possessed developmental characteristics in vitro close to nonbisected controls. A separate transfer of demi-embryos of the two morphological categories to different recipients could clarify this question, which is important for large scale production of twin pigs.

When comparing the developmental potential of microsurgically bisected embryos from various mammals, it is found that survival and twinning rates with demi-embryos in multiparous species are significantly lower than in cattle, sheep or goats $\{50-70 \%$ survival, $40-45 \%$ twinning) (Gatica et al., 1984; Willadsen and Godke, 1984; Takeda et al., 1986; Chesné et al., 1987; Leibo and Rall, 1987; Seike et al., 1989). In contrast, survival of demi-embryos in mice and rabbits is usually impaired and twinning rates of $2-5 \%$ have been obtained (Gärtner and Baunack, 1981; Tsunoda and McLaren, 1983; Nagashima et al., 1984; Ponzilius et al., 1987; Yang and Foote, 1987, 1990). Previously, pig four-cell embryos were bisected, transferred to foreign zonae pellucidae, embedded in agar, cultured in vivo in the sheep oviduct up to the blastocyst stage and blood typing then revealed two sets of identical twins among the piglets born after transfer to the final recipients (Polge, 1985). Nagashima et al. (1988) identified monozygosity in three sets of twin piglets via analysis of nine blood groups and eight proteins. Ash et al. (1989) found two monozygotic pairs of twin piglets via analysis of an unknown number of proteins and through reciprocal skin transplantation. However, in the latter study intact embryos were transferred with the demi-embryos and a significant competition was observed. It is impossible to calculate the twinning rate since in both investigations accurate data on the number of transferred pairs of demi-embryos are not provided. The seven pairs of identical twin piglets obtained in our investigation developed out of 311 pairs of demi-embryos transferred to the farrowing recipients and correspond to a twinning rate of $2.3 \%$, which is similar to values reported for mice (Gärtner and Baunack, 1981; Ponzilius et al., 1987). However, the fact that analysis for monozygosity did not include the stillborn piglets or those that died shortly after birth (a total of 31) should be taken into account as there could have been additional pairs of monozygotic twins.

The analysis of important parameters in pig production revealed some significant differences between the experimental gilts (recipients) and the mated controls. Litter size was significantly reduced in those gilts that had received demiembryos. Potentially, this could have been attributed to a reduced developmental capacity of the transferred demiembryos. However, puberty was induced by hormones in gilts that were used as recipients and it was shown that several endocrinological parameters of gilts in which puberty is induced differ from those of mature gilts, and this finding could be related to the higher early embryonic mortality observed in gilts bred at an induced pubertal oestrus (Rampacek et al., 1985; Kineman et al., 1987; Archibong et al., 1987). However, in a previous study in the same herd, transfer of nonbisected pig embryos after $8-10 \mathrm{~h}$ of culture in vitro to gilts stimulated with a similar protocol led to the same litter size, as observed in the experiment reported here. Postnatal development of the piglets was normal and no differences were found between gilts and sows (Niemann, 1989). In addition, embryos recovered from 
stimulated prepubertal gilts were shown to be cytogenetically normal and capable of regular full term development (Dolch and Chrisman, 1981; Niemann, 1989). Prepubertal gilts can be synchronized easily, have a facilitated handling and were available for our study. As another control, gilts could have received nonbisected embryos but because of the limited number of gilts available and the extended experience with this procedure, the present experimental groups were chosen. It is known that early embryonic mortality due to crowding in the uterus occurs within the first 25 days of pregnancy (Dziuk, 1968; Pope et al., 1972). Further investigations involving detailed analyses of the various sections of the uterine horns could be useful for elucidating potential reasons for the low litter size. The average lower birth weight also showed a larger standard deviation in the piglets from the experimental sows and the fact that these piglets were derived from small litters, which normally have a higher birth weight than piglets from larger litters, leads to the suggestion that at least some bisected embryos undergo impaired fetal development. The greater variation in birth weight could also have contributed to the higher losses of piglets derived from demi-embryos in the early postpartum period.

When comparing birth and weaning weight as well as daily weight gain between the two partners of a monozygotic pair, it is evident that some of the pairs displayed marked differences. In some pairs, the difference observed in birth weight was not apparent at weaning; in others it was observed consistently. Studies involving murine, bovine and human monozygotic twins have shown considerable variation between the two partners which was not obviously attributable to the environment (Gärtner and Baunack, 1981; Levine et al., 1987; Gärtner et al., 1991). These differences were attributed to intangible variation and our results suggest that this variation also occurs in pigs. These, in some cases, distinct differences between monozygotic twin partners could hamper the use of identical twins in some areas of biological research.

In addition to the usual methods of blood typing, DNA fingerprinting was used for the first time to identify monozygosity in pigs. DNA fingerprinting was used to investigate monozygotic fertilization in Large White and the prolific Meishan pigs and a higher incidence of monozygotic fetuses was found in the latter (Ashworth et al., 1993). The accuracy of diagnosis of monozygosity depends on the number of genetic markers analysed, the degree of polymorphy and the gene frequencies. In some of the markers, the degree of polymorphy was very low and the gene frequencies were high. In our case it had to be taken into account that monozygosity was diagnosed among full siblings and that the animals could not be considered as genetically independent from each other. In humans, monozygosity among twin births can be diagnosed with an accuracy of $95-98 \%$ using traditional methods (Nylander, 1970). The confidence level of diagnosing monozygosity with procedures involving multiple gene loci can be calculated as the likelihood of identity (see Jeffreys et al., 1985). This likelihood represents the probability that two individuals are by chance identical at all gene loci. On the basis of the assumption that the population was in the Hardy Weinberg equilibrium and there was no linkage disequilibrium and using the 25 traditional pig blood genetic markers, the calculated probability for each animal of its genotype occurring twice by chance ranged from $3.8 \times 10^{-4}$ to $2.4 \times 10^{-10}$. Under the same assumption, for DNA fingerprinting using only the best visible bands $(n=18)$ involving the banding pattern of 22 animals, this probability was calculated to be less than $1 \times 10^{-7}$. However, this is based on a conservative calculation model taking into account the possibility that different bands may not separate independently and involved the bands in the upper region only. The combination of blood typing plus DNA fingerprinting increased the probability to a range from $3.8 \times 10^{-11}$ to $2.4 \times 10^{-17}$. Future efforts will be directed towards simplifying the determination of monozygosity, for example by applying DNA fingerprinting alone. The likelihood of identity calculated in our experiment for DNA fingerprinting would suggest that this is feasible.

In summary, results from our investigation showed that, in contrast to previous suggestions (Robl and First, 1985), pig morulae and blastocysts can be bisected relatively easily and yield large numbers of viable demi-embryos. When transferring a sufficient number of demi-embryos per recipient, high pregnancy rates can be obtained, although litter size is reduced. Among the piglets born, approximately $2 \%$ identical twins can be positively identified with sufficient security by blood typing and DNA fingerprinting. Monozygotic twin piglets can serve as excellent models in various areas of biological research. The monozygotic twin piglets identified in this study underwent reciprocal skin and pancreas transplantations without showing any type of rejection of the respective graft. Further investigations are necessary to identify factors relevant to the developmental potential of porcine demi-embryos.

The authors are grateful to J. Meyer, Institut für Tierzucht und Haustiergenetik, Universität Göttingen, for the blood typing, serum and enzyme system analyses, J. Buitkamp and J. Epplen, Abterling Molekulare Humangenetik, Ruhr-Universität, Bochum, for the DNA-fingerprinting, D. Herrmann and H. H. Döpke for expert technical assistance during the experiments, J. W. Carnwath, for critical reading of the manuscript and $C$. Knöchelmann for typing the paper. The financial support for $B$. Reichelt from the Deutsche Forschungsgemeinschaft (SFB 330) is gratefully acknowledged.

\section{References}

Arave CW, Bunch TD, Mickelson CH and Warnick K (1987) Factors affecting survivability of transferred whole and demi-embryos in a commercial dairy herd Theriogenology 28 373-382

Archibong AE, England DC and Stormshak F (1987) Factors contributing to early embryonic mortality in gilts bred at first estrus Journal of Animal Science 64 474-478

Ash K, Anderson GB, BonDurant RH, Pashen RL, Parker KM and Berger T (1989) Competition between split and nonmanipulated embryos in the production of identical piglets Theriogenology 31 903-910

Ashworth Cl, Ross AW and Barrett P (1993) The use of DNA fingerprinting to investigate monozygotic fertilization in two breeds of pig Joumal of Reproduction and Fertility Abstract Series 11 Abstract 74

Bazer FW, Robison OW, Clawson AJ and Ulberg LC (1969) Uterine capacity at two stages of gestation in gilts following embryo superinduction Journal of Animal Science 29 30-34

Bredbacka P, Bredbacka K, Aalto J and Kukkola H (1991) Development of inner cell mass in intact and bisected cattle morulae Theriogenology 35188 (Abstract)

Chesné $P$, Colas G, Cognié $Y$, Guerin $Y$ and Sévellec $C$ (1987) Lamb production using superovulation, embryo bisection and transfer Theriogenology 27 $751-757$ 
Davis DL and Day BN (1978) Cleavage and blastocyst formation by pig eggs in vitro Joumal of Animal Science 46 1043-1053

Dolch KM and Chrisman CL (1981) Cytogenetic analysis of preimplantation blastocysts from prepubertal gilts treated with gonadotropins American Joumal of Veterinary Research 42 344-346

Dziuk PJ (1968) Effect of number of embryos and uterine space on embryo survival in the pig Joumal of Animal Science 27 673-676

Dziuk PJ, Polge C and Rowson LEA (1964) Intra-uterine migration and mixing of embryos in swine following egg transfer Joumal of Animal Science $\mathbf{2 3}$ $37-43$

Epplen JT and Zischler H (1991) DNA-Fingerprinting mit OligonukleotidenRadioaktive Markierung und Hybridisierung Fresenius Diagnostik, Borkenberg 14, 6370 Oberursel/TS. 1

Gärtner K and Baunack E (1981) Is the similarity of monozygotic twins due to genetic factors alone? Nature 292 646-647

Gärtner K, Ostheimer C and Rapp K (1991) Der Einfluß der uterinen Umwelt auf Körperlängen und Körpergewicht, untersucht an monozygoten Rinderzwillingen nach Embryotransfer auf eine oder zwei Ammen Reproduction in Domestic Animals 26 235-250

Gatica R, Boland MP, Crosby TT and Gordon I (1984) Micromanipulation of sheep morula to produce monozygotic twins Theriogenology 21 555-560

Gray KR, Bondioli KR and Betts CL (1991) The commercial application of embryo splitting in beef cattle Theriogenology 35 37-44

Grizzle JE, Starmer CF and Koch GG (1969) Analysis of categorical data by linear models Biometrics 25 489-504

Hesselholt M (1966) Studies on serum amylase systems in swine, horses and cattle Royal Veterinary and Agricultural College, Copenhagen, Yearbook 1966 $78-90$

Jeffreys AJ, Wilson V and Thein SL (1985) Individual-specific 'fingerprinting' of human DNA Nature 316 76-79

Juneja RK and Gahne B (1987) Simultaneous phenotyping of pig plasma $\alpha$-protease inhibitors (PI1, PO1A, PO1B, PI2) and four other proteins (PO2, $\mathrm{TF}, \mathrm{CP}, \mathrm{HPX}$ ) by a simple method of $2 \mathrm{D}$ horizontal electrophoresis Animal Genetics 18 197-211

Kineman RD, Rampacek GB, Kraeling RR, Fiorello-Stocks NA and Wilson RL (1987) Comparison of induced corpora lutea from prepubertal gilts and spontaneous corpora lutea from mature gilts: in vitro progesterone production Joumal of Animal Science 64 526-532

Kippax IS, Christie WB and Rowan TG (1991) Effects of method of splitting, stage of development and presence or absence of zona pellucida on fetal survival in commercial embryo transfer of bisected embryos Theriogenology 35 25-35

Leibo SP and Rall WF (1987) Increase in production of pregnancies by bisection of bovine embryos Theriogenology 27245 (Abstract)

Levine RS, Hennekens CH and Jesse MJ (1987) Genetic variance of weight and length in infant twins American Journal of Epidemiology 126 929-935

McEvoy TG and Sreenan JM (1990) Effect of embryo quality and stage of development on the survival of zona pellucida-free cattle demi-embryos Theriogenology 33 1245-1253

Miller SA, Dykes DD and Polesky HF (1988) A simple salting out procedure for extracting DNA from human nucleated cells Nucleic Acids Research 161215 (Abstract)

Nagashima H, Matsui K, Sawasaki T and Kano Y (1984) Production of monozygotic mouse twins from microsurgically bisected morulae Journal of Reproduction and Fertility 70 357-362

Nagashima H, Katoh J, Shibata K and Ogawa S (1988) Production of normal piglets from microsurgically split morulae and blastocysts Theriogenology 29 485-495

Nagashima H, Kato Y and Ogawa S (1989) Microsurgical bisection of porcine morulae and blastocysts to produce monozygotic twin pregnancy Gamete Research 23 1-9

Nakamura G, Leppert M, O'Connell P, Wolff R, Holm T, Culver M, Martin C, Fujimoto E, Hoff M, Kumlin E and White R (1987) Variable number of tandem repeat (VNTR) markers for human gene mapping Science 235 1616-1622

Niemann H (1989) Biotechnologische Studien an präimplantatorischen Embryonen von Rind und Schwein pp 93-102. Ferdinand Enke Verlag, Stuttgart

Niemann H and Elsaesser F (1987) Steroid hormones in early pig embryo development. In The Mammalian Preimplantation Embryo: Regulation of Growth and Development pp 117-132 Ed. BD Bavister. Plenum Press, New York

Niemann H and Reichelt B (1993) Manipulating the early porcine embryo Journal of Reproduction and Fertility Supplement 48 75-94
Niemann H, Illera MJ and Dziuk PJ (1983a) Developmental capacity, size and number of nuclei in pig embryos cultured in vitro Animal Reproduction Science 5 311-321

Niemann H, Illera MJ and Smidt D (1983b) In vitro development of pig morulae after enzymatic removal or microsurgical treatment of the zona pellucida Theriogenology 19142 (Abstract)

Nylander PPS (1970) The determination of zygosity - a study of 608 pairs of twins born in Aberdeen Joumal of Obstetrics and Gynaecology of the British Commonwealth 77 506-510

Ozil JP (1983) Production of identical twins by bisection of blastocysts in the cow Journal of Reproduction and Fertility 69 463-468

Pemberton J and Amos B (1990) DNA fingerprinting: a new dimension Trends in Genetics 6 101-103

Picard L, Greve T, King WA, Betteridge KJ and Holm Jorgensen P (1986) Bisection of post-compaction bovine-embryos: the difference in viability between the two monozygotic halves Acta Veterinaria Scandinavica 27 $33-48$

Polge C (1982) Embryo transplantation in the pig Proceedings of the Second World Conference of Embryo Transfer and In Vitro Fertilization, pp 235-242 Eds C Merieux and M Bonneau. SCIT, Europe

Polge C (1985) How does embryo manipulation fit into present and future pig reproduction? Journal of Reproduction and Fertility Supplement 33 93-100

Polge C, Rowson LEA and Chang MC (1966) The effect of reducing the number of embryos during early stages of gestation on the maintenance of pregnancy in the pig Journal of Reproduction and Fertility 12 395-397

Ponzilius KH, Nagai T, Marcus GJ and Hackett AJ (1987) Survival of bisected mouse embryos after exposure to pronase and medium free of calcium and magnesium Theriogenology 27 859-867

Pope CE and Day BN (1977) Transfer of preimplantation pig embryos following in vitro culture for 24 or $48 \mathrm{hrs}$ journal of Animal Science 44 1036-1040

Pope CE, Christensen RK, Zimmermann-Pope VA and Day BN (1972) Effect of number of embryos on embryonic survival in recipient gilts Journal of Animal Science 35 805-808

Pope WF, Xie S, Broermann DM and Nephew KP (1990) Causes and consequences of early embryonic diversity in pigs Journal of Reproduction and Fertility Supplement $40251-260$

Rampacek GB, Kraeling RR and Pinkert CA (1985) Regression of induced corpora lutea by human chorionic gonadotropin in prepubertal gilts Joumal of Animal Science 60 1040-1044

Robl JM and First NL (1985) Manipulation of gametes and embryos in the pig Joumal of Reproduction and Fertility Supplement 33 101-114

Saito S and Niemann H (1991) Effects of extracellular matrices and growth factors on the development of isolated porcine blastomeres Biology of Reproduction 44 927-936

Saito S, Nienhaus P and Niemann H (1991) Developmental ability of bisected and aggregated porcine embryos in vitro Theriogenology 35267 (Abstract)

Schmid DO and Buschmann HG (1985) Blutgruppen bei Tieren, pp 165-200 Ferdinand Enke Verlag, Stuttgart

Schwaiger FW, Gomolka M, Geldermann H, Zischler H, Buitkamp J, Epplen JT and Ammer $\mathbf{H}$ (1992) Oligonucleotide fingerprinting to individualize ungulates Applied and Theoretical Electrophoresis 2 193-200

Searle SR (1971) Linear models. John Wiley \& Sons, New York

Seike N, Saeki K, Utaka K, Sakai M, Takakura R, Nagao Y and Kanagawa H (1989) Production of bovine identical twins via transfer of demi-embryos without zonae pellucidae Theriogenology 32 211-220

Shelton JN (1992) Factors affecting viability of fresh and frozen-thawed sheep demi-embryos Theriogenology 37 713-721

Shelton JN and Széll A (1988) Survival of sheep demi-embryos in vivo and in vitro Theriogenology $30855-863$

Skrzyszowska i and Smorag Z (1989) Cell loss in bisected mouse, sheep and cow embryos Theriogenology 32 115-122

Széll A and Hudson RHH (1991) Factors affecting the survival of bisected sheep embryos in vivo Theriogenology 36 379-387

Takeda T, Hallowell SV, McCauley AD and Hasler JF (1986) Pregnancy rates with intact and split bovine embryos transferred surgically and nonsurgically Theriogenology 25204 (Abstract)

Tarkowski AK (1966) An air-drying method for chromosome preparation from mouse eggs Cytogenetics 5 394-400

Tsunoda Y and McLaren A (1983) Effect of various procedures on the viability of mouse embryos containing half the normal number of blastomeres Journal of Reproduction and Fertility 69 315-322 
Tsunoda $Y$, Tokunaga T, Sugie $T$ and Katsumata $M$ (1985) Production of monozygotic twins following the transfer of bisected embryos in goats Theriogenology 24 337-343

Udy GB (1987) Commercial splitting of goat embryos Theriogenology 28 $837-847$

Verhorst D (1973) Enzym- und Serumproteinpolymorphismen in Schweinezuchtlinien. PhD Dissertation, University of Göttingen

Vögeli P (1990) Blutgruppen des Schweins - serologische und genetische Studien Habilschrift ETH, Zürich

Webel SK, Peters JB and Anderson LL (1970) Synchronous and asynchronous transfer of embryos in the pig Journal of Animal Science 30 565-568
Willadsen SM and Godke RA (1984) A simple procedure for the production of identical sheep twins Veterinary Record 114 240-242

Williams TJ, Elsden RP and Seidel GE, Jr (1984) Pregnancy rates with bisected bovine embryos Theriogenology 22 521-531

Yang $X$ and Foote RH (1987) Production of identical twin rabbits by micromanipulation of embryos Biology of Reproduction 37 1007-1014

Yang $X$ and Foote RH (1990) Survival of bisected rabbit morulae transferred to synchronous and asynchronous recipients Molecular Reproduction and Development 26 6-11 